Wojciech Papis https://orcid.org/0000-0001-9308-0019

Wyższa Szkoła Humanitas w Sosnowcu

Anna Rogacka-tukasik (i) https://orcid.org/0000-0001-6140-0591

Wyższa Szkoła Humanitas w Sosnowcu

\title{
CZAS PRACY OSÓB NIEPEŁNOSPRAWNYCH NA PODSTAWIE WYBRANYCH REGULACJI PRAWNYCH
}

\author{
Abstract \\ Working time of disabled people based on selected legal regulations
}

This study aims to present selected legal regulations concerning the working time of disabled people. The authors, in the examples of specific lex specialis regulations in relation to the provisions of the Act of 27 August 1997 on vocational and social rehabilitation as well as employing people with disabilities, show the complexity of the subject issue of this legal problem. The conducted considerations aim, apart from presenting some discrepancies in the subject matter, to show the multiplicity of legal solutions that make it possible to apply an equivalent system of working time to people with disabilities. They point to the restrictions on the application of regulations regarding the possibility of prolonging working time resulting from specific provisions regulating this issue for people with disabilities.

Słowa kluczowe: osoby niepełnosprawne, czas pracy, prawo pracy, równoważny system czasu pracy, przedłużenie czasu pracy, przedłużenie okresu rozliczeniowego

Keywords: disabled persons, working time, labor law, an equivalent system of working time, extension of working time, extension of the billing period

ASJC: 3308, JEL: K31

\section{Wstęp}

W ramach polityki społecznej zarówno podmioty publiczne, jak też organizacje pozarządowe podejmują szereg działań wobec osób niepełnosprawnych (pojawia się tendencja do zmiany nazewnictwa na „osoby z niepełnosprawnościami”). Celem jest utworzenie ogólnych warunków pracy oraz funkcjonowania osób niepełnosprawnych 
we wszystkich dziedzinach życia gospodarczego i społecznego oraz umożliwienie pełnej integracji ze społeczeństwem (Kurzynowski 1996, s. 4-5). Osoby niepełnosprawne znajdują się w specyficznej sytuacji zwłaszcza na rynku pracy, gdyż aby móc w pełni uczestniczyć w życiu społecznym, muszą pokonywać własne ograniczenia oraz niestety uprzedzenia odnoszące się do ich wydajności pracy (Paluszkiewicz 2018, s. 639-640). Dlatego też osoby niepełnosprawne zostały uznane przez prawodawcę za szczególną kategorię osób na rynku pracy, a o potrzebie ich wyróżnienia świadczy ich trudna pozycja w tym obszarze życia, ale również wielość skomplikowanych i kazuistycznych regulacji prawnych, w których ustawodawca nadal operuje nomenklaturą o negatywnym zabarwieniu, taką jak na przykład: „,inwalidztwo”, „kalectwo” bądź „niezdolność do pracy". Jednym z zagadnień regulowanych przez wiele aktów prawnych, częstokroć w odmienny sposób, jest problematyka czasu pracy osób niepełnosprawnych (pracowników niepełnosprawnych).

Pojęcie czasu pracy uregulowane zostało w prawie europejskim na gruncie art. 2 pkt 1 Dyrektywy 2003/88/WE Parlamentu Europejskiego i Rady z dn. 4 listopada 2003 r. dotyczącej niektórych aspektów organizacji czasu pracy (Dz.Urz. UE L 2003, nr 299, s. 9), gdzie ustawodawca unijny obejmuje zakresem tego pojęcia trzy elementy. Pierwszy dotyczy świadczenia pracy przez pracownika, drugi - pozostawania w dyspozycji pracodawcy, a trzeci postaci wykonywania obowiązków. Definicja unijna czasu pracy nie została w pełni przeniesiona na grunt prawa polskiego, gdyż polska definicja legalna czasu pracy, ujęta w art. $128 \$ 1$ ustawy z dn. 26 czerwca 1974 r. - Kodeks pracy (Dz.U. 2018, poz. 917 tekst jedn. ze zm., dalej: „Kodeks pracy”, „k.p.”), zawiera dwa elementy: pozostawanie w dyspozycji oraz obecność w miejscu pracy (Stefański 2018a, s. 789). Kodeksowa definicja czasu pracy uzupełniana jest także przez praktykę orzeczniczą.

I tak przykładowo Sąd Najwyższy w wyroku z 23 czerwca 2005 r. (II PK 265/04, OSNP 2006, nr 5-6, poz. 76) wskazał, iż czas pracy jest określonym w jednostkach czasu miernikiem pozostawania pracownika $\mathrm{w}$ dyspozycji pracodawcy, jak również miarą zakresu świadczenia pracy decydującą o zakresie uprawnienia pracownika do wynagrodzenia za pracę i innych świadczeń związanych z pracą. Należy mieć na względzie spore trudności, jakie przynoszą niektóre rozwiązania szczegółowe, głównie regulacji dyżuru pracowniczego bądź pracy w godzinach nadliczbowych (Stefański 2018a, s. 874; Bury 2007; Gersdorf 2004; Rączka 2004)1', jednakże z uwagi na przyjętą tematykę niniejszej publikacji i obszerność wskazanych zagadnień problematycznych zostają one jedynie zasygnalizowane.

Normy czasu pracy osób niepełnosprawnych zostały uregulowane w odmienny sposób $\mathrm{w}$ porównaniu z pracownikami pełnosprawnymi, co ma swoje korzenie w powojennych regulacjach prawnych ( $\$ 11$ Rozporząazenia Rady Ministrów z dn. 5 maja 1967 r. w sprawie zatrudniania inwalidów, Dz.U. 1967, nr 20, poz. 88 ze zm.). Czas pracy pracowników niepełnosprawnych polski ustawodawca uregulował w ustawie

1 We wszystkich przypisach literatura wykazana została zgodnie z kryterium ważności (zamiast chronologicznego). 
z dn. 27 sierpnia 1997 r. o rehabilitacji zawodowej i społecznej oraz zatrudnianiu osób niepełnosprawnych (Dz.U. 2018, poz. 511 tekst jedn. ze zm., dalej: „ustawa o rehabilitacji zawodowej i społecznej oraz zatrudnianiu osób niepełnosprawnych”, „u.r.z.o.n.”). Jednakże przedmiotowa ustawa nie reguluje kompleksowo problematyki czasu pracy, gdyż na przykład nie odnosi się do sposobu ustalania wymiaru czasu pracy dla pracowników niepełnosprawnych, stąd na mocy art. 5 k.p. będą w tym zakresie stosowane przepisy Kodeksu pracy. Artykuł 5 k.p. wyraża generalną zasadę lex specialis derogat legi generali (Zieliński, Goździewicz 2017, s. 70-71). Wybrane kategorie pracowników (art. 5 k.p. odnosi się tylko i wyłącznie do pracowników, nie dotyczy zaś funkcjonariuszy państwowych wykonujących służbę na podstawie stosunku administracyjnoprawnego; Dörre-Kolasa 2018, s. 14) podlegają regulacjom szczególnym, a Kodeks pracy ma do nich zastosowanie jako lex generalis, a zatem w takim zakresie, w jakim odrębne przepisy szczególne lex specialis nie zawierają odmiennych regulacji. Na gruncie art. 5 k.p. ustawodawca stworzył subsydiarny mechanizm stosowania norm Kodeksu pracy odnośnie do regulacji statusu pracowników, których stosunek pracy jest określany przez przepisy szczególne (Baran 2018, s. 60). Co ważne, poprzez art. 5 k.p. wskazano, że Kodeks pracy można stosować wprost w zakresie nieuregulowanym w pragmatyce (uchwała SN z 8 kwietnia 2009, II PZP 2/09, OSNP 2009, nr 19-20, poz. 249).

\section{Czas pracy osób niepełnosprawnych na gruncie ustawy o rehabilitacji zawodowej i społecznej oraz zatrudnianiu osób niepełnosprawnych}

Sięgając już bezpośrednio do przepisów ustawy o rehabilitacji zawodowej i społecznej oraz zatrudnianiu osób niepełnosprawnych, należy przede wszystkim odwołać się do dwóch artykułów tej ustawy, a mianowicie art. 15 i 16. Dokonując wykładni treści tych dwóch artykułów pod kątem tematu rozważań niniejszej publikacji, można wyróżnić następujące przypadki specyfiki regulacji czasu pracy osób niepełnosprawnych;

1) wynikające z przedmiotowej ustawy ograniczenia czasu pracy osób niepełnosprawnych:

a. czas pracy osób o lekkim stopniu niepełnosprawności (nie może przekraczać 8 godzin dziennie i 40 godzin tygodniowo),

b. czas pracy osób o umiarkowanym i znacznym stopniu niepełnosprawności (nie może przekraczać 7 godzin na dobę i 35 godzin tygodniowo),

c. zakaz zatrudniania osób niepełnosprawnych w godzinach nocnych i nadliczbowych;

2) wynikające z komentowanej ustawy wyłączenie stosowania przepisów określonych w pkt 1:

a. w stosunku do osób zatrudnionych przy pilnowaniu (dozór mienia w definicji ustawy z dn. 22 sierpnia 1997 r. o ochronie osób i mienia, Dz.U. 2018, poz. 2142 tekst jedn. ze zm., dalej: „u.o.m.”), 
b. w sytuacji gdy na wniosek osoby zatrudnionej lekarz przeprowadzający badania profilaktyczne pracowników lub w razie jego braku lekarz sprawujący opiekę nad tą osobą wyrazi na to zgodę;

3) specyficzne (lex specialis) regulacje prawne wynikające z innych aktów normatywnych, które normują wykonywanie określonych zawodów, mające zastosowanie do pracowników niepełnosprawnych przy spełnieniu określonych prawem wymogów.

Na wstępie należy wyjaśnić pojęcia lekkiego, umiarkowanego i znacznego stopnia niepełnosprawności. Ogólną definicję niepełnosprawności możemy znaleźć już na gruncie samej ustawy o rehabilitacji zawodowej i społecznej oraz zatrudnianiu osób niepełnosprawnych, gdzie oznacza ona trwałą lub okresową niezdolność do wypełniania ról społecznych z powodu stałego lub długotrwałego naruszenia sprawności organizmu, w szczególności powodującą niezdolność do pracy (art. 2 pkt 10 u.r.z.o.n.). Przechodząc do definicji znacznego stopnia niepełnosprawności, według art. 4 ust. 1 u.r.z.o.n.:

[...] oznacza to trwałą lub okresową niezdolność do wypełniania ról społecznych z powodu stałego lub długotrwałego naruszenia sprawności organizmu, w szczególności powodującą niezdolność do pracy.

\section{Z kolei:}

Do umiarkowanego stopnia niepełnosprawności zalicza się osobę z naruszoną sprawnością organizmu, niezdolną do pracy albo zdolną do pracy jedynie w warunkach pracy chronionej lub wymagającą czasowej albo częściowej pomocy innych osób w celu pełnienia ról społecznych.

\section{Natomiast:}

Do lekkiego stopnia niepełnosprawności zalicza się osobę o naruszonej sprawności organizmu, powodującej w sposób istotny obniżenie zdolności do wykonywania pracy, w porównaniu do zdolności, jaką wykazuje osoba o podobnych kwalifikacjach zawodowych z pełną sprawnością psychiczną i fizyczną, lub mająca ograniczenia w pełnieniu ról społecznych dające się kompensować przy pomocy wyposażenia w przedmioty ortopedyczne, środki pomocnicze lub środki techniczne.

W zależności od stopnia niepełnosprawności ustawodawca na gruncie regulacji ustawy o rehabilitacji zawodowej i społecznej oraz zatrudnianiu osób niepełnosprawnych skraca zarówno dzienny, jak i tygodniowy wymiar czasu pracy. Celem dokładnego wyjaśnienia problemu skróconego czasu pracy osób niepełnosprawnych wskazać należy, że do dn. 9 lipca 2014 r. obowiązywał przepis art. 15 ust. 2a² u.r.z.o.n., w którym stosowanie skróconej normy czasu pracy określonej w art. 15 ust. 2 u.r.z.o.n. (nie więcej

2 W związku z wyrokiem TK z 13 czerwca 2013 r. (K 17/11, Dz.U. 2013, poz. 791) art. 15 ust. 2a został uznany za niezgodny z art. 2 w zw. z art. 69 Konstytucji RP (Dz.U. 1997, nr 78, poz. 483 ze zm.) w zakresie, $\mathrm{w}$ jakim zastosowanie skróconego czasu pracy do osoby niepełnosprawnej zaliczonej do znacznego 
niż 7 godzin dziennie i 35 godzin tygodniowo) wobec osób o znacznej i umiarkowanej niepełnosprawności uzależniano od uzyskania od lekarza zaświadczenia o celowości stosowania skróconego czasu pracy w stosunku do tych osób (Staszewska 2015, s. 371-372). Obecnie stosowanie powyżej wymienionych wymiarów czasu pracy wymaga uzyskania zaświadczenia lekarskiego o braku przeciwskazań dla osoby niepełnosprawnej (dotyczy to pracy w wymiarze ponad 40 godzin tygodniowo i 8 godzin dziennie), a wobec osób o znacznej i umiarkowanej niepełnosprawności również zastosowanie czasu pracy w wymiarze 35 godzin tygodniowo i 7 godzin dziennie wymaga wydania takiego zaświadczenia.

Uzupełniając, należy również wspomnieć o zakazie pracy dla osób niepełnosprawnych w porze nocnej i godzinach nadliczbowych (art. 15 ust. 3 u.r.z.o.n.). Ochrona w tym zakresie dotyczy wszystkich osób niepełnosprawnych, które przedstawią pracodawcy orzeczenie potwierdzające niepełnosprawność. W zakresie zarówno samego pojęcia pory nocnej, jak też pracy w godzinach nadliczbowych ustawodawca odsyła nas - poprzez regulację art. 66 ust. 1 u.r.z.o.n. - do definicji wyrażonych na gruncie Kodeksu pracy. Warto nadmienić, iż pora nocna obejmuje 8 godzin (między 21:00 a 7:00), co wynika wprost $\mathrm{z}$ art. $151^{7} \$ 1 \mathrm{k} . \mathrm{p}$. (godziny te wyznacza pracodawca i określa $\mathrm{w}$ regulaminie pracy). $Z$ kolei praca wykonywana ponad obowiązujące pracownika normy czasu pracy, a także praca wykonywana ponad przedłużony dobowy wymiar czasu pracy, wynikający z obowiązującego pracownika systemu i rozkładu czasu pracy, stanowi prace w godzinach nadliczbowych. Praca w godzinach nadliczbowych jest dopuszczalna w razie konieczności prowadzenia akcji ratowniczej w celu ochrony życia lub zdrowia ludzkiego, ochrony mienia lub środowiska albo usunięcia awarii oraz w razie szczególnych potrzeb pracodawcy (art. $151 \$ 1$ k.p.).

Odnosząc powyższe do osób niepełnosprawnych, należy stwierdzić, że praca nadliczbowa będzie praca ponad normy czasu pracy mające zastosowanie do konkretnego pracownika (Klimkiewicz 2011, s. 18). Zatem dla osoby niepełnosprawnej, którą obowiązuje ośmiogodzinna norma czasu pracy, pracą w godzinach nadliczbowych będzie praca ponad tę normę; z kolei w sytuacji osób niepełnosprawnych, które korzystają ze skróconej normy czasu pracy w wymiarze 7 godzin, będzie to praca ponad tę normę. Natomiast jeśli osoba niepełnosprawna korzysta, na podstawie szczególnych przepisów, z jeszcze krótszej normy czasu pracy, wówczas pracą w godzinach nadliczbowych będzie praca ponad tę krótszą normę.

Zwrócić trzeba dodatkowo uwagę na swoiste regulacje prawne, które pozwalają na zastosowanie przez pracodawców wobec pracowników niepełnosprawnych równoważnego systemu czasu pracy oraz przerywanego czasu pracy - co zostanie omówione poniżej, podczas analizy szczegółowych rozwiązań prawnych w określonych rodzajach zawodów.

lub umiarkowanego stopnia niepełnosprawności uzależniał od uzyskania zaświadczenia lekarskiego o celowości stosowania skróconej normy czasu pracy, i stracił moc w tym zakresie z dn. 10 lipca 2014 r. 


\section{Czas pracy osób niepełnosprawnych w określonych rodzajach zawodów}

\subsection{Czas pracy osób niepełnosprawnych zatrudnionych przy pilnowaniu}

Przepis art. 16 ust. 1 pkt 1 u.r.z.o.n. dotyczy osób niepełnosprawnych zatrudnionych przy pilnowaniu (ochronie mienia i osób). W przypadku gdy lekarz prowadzący badania profilaktyczne lub lekarz sprawujący opiekę nad takimi osobami wyrazi zgodę, można zastosować wobec nich nie tylko wydłużony ponad normy wynikające $\mathrm{z}$ art. 15 u.r.z.o.n. czas pracy (godziny nadliczbowe i godziny pracy w porze nocnej), ale również ruchomy rozkład czasu pracy określony zgodnie z art. $140^{1}$ k.p., oraz zastosować zgodnie z art. 137 w zw. z art. $135 \$ 2$ i 3 k.p. system równoważnego czasu pracy w okresie rozliczeniowym do 3 albo 4 miesięcy. W ramach ruchomego czasu pracy możliwe jest zatrudnianie pracownika dwukrotnie w tej samej dobie. Należy zauważyć, iż jest to pierwszy w Kodeksie pracy wyjątek od generalnej zasady nienaruszalności doby pracowniczej. Ta zasada nie pozwala wyznaczyć pracownikowi godziny rozpoczęcia pracy przed upływem 24 godzin, licząc od godziny rozpoczęcia przez niego pracy w dniu poprzednim. Dodatkowo jeżeli pracownik świadczy pracę po raz drugi w trakcie tej samej doby pracowniczej, stanowi to pracę nadliczbową (Stefański 2018b, s. 464). Co do tzw. systemu równoważnego czasu pracy - podobnie jak w pierwszym przypadku można go zastosować wobec osoby niepełnosprawnej, gdy wyrazi na to zgodę lekarz i ta osoba pracuje przy ochronie osób i mienia (przy czym oba te warunki winny być spełnione łącznie w przypadku ruchomego rozkładu pracy i systemu równoważnego czasu pracy). „Istotą równoważnego systemu pracy jest możliwość przedłużania dobowej normy czasu pracy ponad 8 godzin. Okres dłuższego świadczenia pracy jest rekompensowany krótszym jej wykonywaniem w innych dniach lub dniami wolnymi” (Stefański 2018b, s. 452). Zauważyć należy w tym miejscu, że taki system można stosować wyłącznie w określonych sytuacjach spowodowanych specyfiką zatrudnienia (określona kategoria pracowników) - zgodnie z art. 137 k.p. obejmuje on przede wszystkim pracowników zatrudnionych przy pilnowaniu mienia i ochronie osób (Stefański 2018b, s. 454).

Wracając do zagadnienia ruchomego rozkładu czasu pracy, zaznaczyć trzeba, iż zgodnie $\mathrm{z}$ art. $150 \$ 5$ k.p. tego typu rozkład może być zastosowany również na pisemny wniosek pracownika - regulacja ta ma charakter uniwersalny dla wszystkich pracowników - warto podkreślić, że tego typu rozwiązanie może mieć zastosowanie nie tylko w przypadku uzasadnionych potrzeb pracodawcy (aczkolwiek przepis nie wskazuje konkretnych przesłanek zastosowania tegoż przepisu), ale również - na co zwrócono uwagę powyżej - na wniosek pracownika, co można bardzo łatwo skojarzyć z potrzebami pracownika niepełnosprawnego wynikającymi na przykład z konieczności uczęszczania na zabiegi rehabilitacyjne. Natomiast poruszenie zagadnienia dotyczącego ruchomego czasu pracy przy okazji omawiania rozwiązań prawnych dotyczących ochrony mienia można uzasadnić niekiedy nietypowymi zadaniami ochronnymi, przykładowo 
wynikającymi z ochrony osób i mienia w związku z konwojowaniem wartości pieniężnych o określonych godzinach.

Realia polskiego rynku pracy spowodowały, że powszechnym zjawiskiem stało się funkcjonowanie tzw. agencji ochrony jako zakładów pracy chronionej. Omówienie, jaki ma to wpływ na jakość świadczonych usług, nie mieści się w zakresie tego opracowania, na pewno jednak rodzaj wykonywanej przez nie działalności wymaga zatrudniania przynajmniej w części osób, które charakteryzują się wysoką sprawnością fizyczną i dobrym stanem zdrowia.

\subsection{Czas pracy niepełnosprawnych nauczycieli}

Ze szczególną regulacją czasu pracy osób niepełnosprawnych spotkać się można również w przypadku nauczycieli szkół podstawowych i ponadpodstawowych, zgodnie z ustawą z dn. 26 stycznia 1982 r. - Karta Nauczyciela (Dz.U. 2018, poz. 967 tekst jedn. ze zm., dalej: „K.N.”). W art. 42a ust. 1a K.N. określono, że w przypadku nauczyciela niepełnosprawnego, zaliczonego do znacznego lub umiarkowanego stopnia niepełnosprawności, dla którego maksymalny wymiar czasu pracy jest ustalany zgodnie $\mathrm{z}$ art. 15 ust. 2 u.z.r.o.n., obniża się tygodniowy obowiązkowy wymiar godzin zajęć proporcjonalnie do obniżenia maksymalnego tygodniowego wymiaru czasu pracy, z zaokrągleniem do pełnych godzin w ten sposób, że czas zajęć do pół godziny pomija się, a powyżej pół godziny liczy się za pełną godzinę. Zgodnie z art. 15 ust. 2 u.r.z.o.n. czas pracy osoby niepełnosprawnej nie może przekraczać 8 godzin na dobę i 40 godzin tygodniowo, natomiast czas pracy osoby niepełnosprawnej zaliczonej do znacznego lub umiarkowanego stopnia niepełnosprawności nie może przekraczać 7 godzin na dobę i 35 godzin tygodniowo. Osoba niepełnosprawna nie może być zatrudniona w porze nocnej i w godzinach nadliczbowych. Uwzględniając szczególną regulację przywoływanego powyżej art. 42a ust. 1a K.N., należy podnieść, iż tygodniowy obowiązkowy wymiar godzin zajęć obniża się proporcjonalnie do obniżenia maksymalnego tygodniowego wymiaru czasu pracy, z zaokrągleniem do pełnych godzin w ten sposób, że czas zajęć do pół godziny pomija się, a powyżej pół godziny liczy się za pełną godzinę. Z praktycznego punktu widzenia nauczyciel, którego tygodniowy obowiązkowy wymiar zajęć powinien wynosić 18 godzin, a zgodnie z ustawą jego tygodniowy czas pracy to 35 godzin, obniżone pensum powinien realizować w wymiarze 16 godzin. Powyższe wyklucza możliwość przydzielenia nauczycielowi godzin ponadwymiarowych. Obniżonego wymiaru czasu pracy nie stosuje się, gdy na wniosek nauczyciela lekarz przeprowadzający badania profilaktyczne lub w razie jego braku lekarz sprawujący opiekę nad tym nauczycielem wyrazi na to zgodę (Barański, Szymańska, Rozwadowska-Skrzeczyńska 2018, s. 388-389). W celu ustalenia podstawy wymiaru godzin zajęć konieczne jest sięgnięcie do tabeli przedstawionej w art. 42 ust. 3 K.N., ustalającej „tygodniowy obowiązkowy wymiar godzin zajęć dydaktycznych, wychowawczych i opiekuńczych, prowadzonych bezpośrednio z uczniami lub wychowankami albo na ich rzecz, nauczycieli zatrudnionych w pełnym wymiarze zajęć”. 
Dodatkowo należy zwrócić uwagę na przepis art. 42a ust. 1 K.N., w którym stanowi się o prawie organu prowadzącego szkołę lub placówkę do określenia przypadków, w jakich nauczycielowi zatrudnionemu w pełnym wymiarze zajęć można obniżyć tygodniowy obowiązkowy wymiar godzin zajęć, oraz warunków i trybu tego obniżenia. Zwrócić uwagę należy na specyficzną sytuacje nauczycieli zajmujących stanowiska kierownicze:

\begin{abstract}
Nauczyciele zajmujący stanowiska kierownicze w szkole realizują zajęcia w obniżonym wymiarze w stosunku do obowiązującego bądź też są w ogóle zwolnieni z realizacji tygodniowego obowiązkowego wymiaru godzin zajęć. Skala obniżki zależy od wielkości i typu szkoły oraz warunków pracy. Zasady udzielania i rozmiar obniżki określa organ prowadzący szkołę (rada gminy, rada powiatu, sejmik województwa) [...] Należy pamiętać, że czas pracy nauczyciela zajmującego stanowisko kierownicze w szkole wynosi również 40 godzin na tydzień (Barański, Szymańska, Rozwadowska-Skrzeczyńska 2018, s. 385).
\end{abstract}

W takim przypadku należy przyjąć, że wobec niepełnosprawnego nauczyciela zajmującego kierownicze stanowisko w szkole należy stosować ogólne przepisy ustawy o rehabilitacji zawodowej i społecznej osób niepełnosprawnych. Za taką wykładnią przemawia również treść przepisu art. $42 \mathrm{a}$ ust. $3 \mathrm{~K} . \mathrm{N}$., w którym postanowiono, że nauczycielom korzystającym z obniżonego obowiązkowego tygodniowego wymiaru godzin zajęć nie przydziela się godzin ponadwymiarowych.

\title{
2.3. Czas pracy niepełnosprawnych pracowników kultury
}

Omawiając zagadnienie czasu pracy niepełnosprawnych pracowników kultury, zaznaczyć trzeba, że w ustawie z dn. 25 października 1991 r. o organizowaniu i prowadzeniu działalności kulturalnej (Dz.U. 2018, poz. 1983 tekst jedn. ze zm., dalej: „ustawa o organizowaniu i prowadzeniu działalności kulturalnej”, „u.o.p.d.k.”) brak jest szczególnych regulacji czasu pracy dla pracowników kultury będących osobami niepełnosprawnymi, jednak nie wymienia się tego rodzaju pracowników w przepisie art. 137 k.p., jak to ma miejsce w przypadku osób zatrudnionych przy pilnowaniu mienia lub ochronie osób, pracowników zakładowych straży pożarnych i zakładowych służb ratowniczych, wobec których można stosować system równoważnego czasu pracy określony w art. 135 k.p. Szczególny nacisk w tym miejscu położyć należy na fakt, że:

Nie ma jednak pełnej swobody we wprowadzaniu systemów równoważnych, nie można ich utożsamiać z pełną dowolnością [...] ocenę charakteru pracy lub jej organizacji pozostawiono pracodawcy, który ostateczną decyzję podejmuje samodzielnie lub wspólnie ze związkami zawodowymi. Oceny, czy istniało uzasadnienie dla stosowania równoważnego czasu pracy, może dokonać PIP przy wykorzystaniu ogólnych instrumentów kontrolnych. W skrajnych przypadkach nieuzasadnione wprowadzenie równoważnego czasu pracy może zostać zakwalifikowane jako wykroczenie przeciw prawom pracownika (Pisarczyk 2017, s. 824). 
Odnosząc się do powyższego, podkreślić należy, że na pewno osób niepełnosprawnych nie będzie można zatrudnić przy wykonywaniu pracy w zakładowych strażach pożarnych czy też zakładowych służbach ratowniczych - ze względu na charakter wykonywanej pracy, która wymaga bardzo dobrego stanu zdrowia i sprawności fizycznej - natomiast osoby takie mogą znaleźć zatrudnienie w instytucjach kultury (np. w teatrach, operach, operetkach). Jak już powyżej zaznaczono, osoby te mogą zostać zatrudnione także w agencjach ochrony (część $\mathrm{z}$ nich funkcjonuje nawet jako zakłady pracy chronionej), w związku z czym zastosowanie znajduje w ich przypadku art. 135 w zw. z art. 137 k.p., ponieważ - jak wspomniano wyżej - choć nie można stosować dowolnie równoważnego systemu czasu pracy, to jednak można powziąć wątpliwość co do zasadności stosowania systemu równoważnego w przypadku pracowników kultury.

Problem ten został rozstrzygnięty wspomnianą ustawą o organizowaniu i prowadzeniu działalności kulturalnej. w art. 26b przewidziano możliwość przedłużenia okresu rozliczeniowego do 12 miesięcy. Jest to więc regulacja szczególna w stosunku do art. 135 k.p., która jednak nie wyłącza stosowania ogólnych przepisów kodeksu pracy w tym zakresie (Gajewski, Jakubowski 2016, s. 150). Przedłużenie okresu rozliczeniowego w przypadku pracowników kultury uzasadnione jest możliwością dostosowania okresów rozliczeniowych do specyfiki pracy poszczególnych instytucji kultury i nabiera szczególnego znaczenia w odniesieniu do instytucji artystycznych, w których praca jest podporządkowana sezonom artystycznym, zgodnie z planami repertuarowymi (Gajewski, Jakubowski 2016, s. 149-150). Z kolei w art. 26c u.o.p.d.k. ustawodawca dopuszcza możliwość zastosowania przerywanego czasu pracy dla pracowników instytucji kultury - według z góry ustalonego rozkładu, przewidującego nie więcej niż jedną przerwę w pracy w ciągu doby, trwającą nie dłużej niż 5 godzin.

$\mathrm{W}$ tym miejscu ponownie należy rozpatrzyć, w jakiej relacji regulacja tego przepisu pozostaje do postanowień Kodeksu pracy, a w szczególności do art. $139 \$ 1$ k.p. Czy w takim przypadku pracownik kultury ma prawo do wynagrodzenia w wysokości 50\% należnego za czas przestoju za okres przerwy miedzy dwoma jednostkami czasu pracy? Według poglądów przedstawicieli doktryny:

Skoro bowiem do pracowników instytucji kultury stosuje się przepisy kodeksu pracy w zakresie, w jakim nie zostały one wprost zmodyfikowane przez komentowaną ustawę, to nie można przyjąć, by niepowtórzenie statuującego wspomniane uprawnienie fragmentu art. $139 \$ 1$ k.p. przez art. 26c ust. 2 u.o.p.d.k. wyłączało zastosowanie tego przepisu (Gajewski, Jakubowski 2016, s. 152).

Podsumowując, warunkiem zastosowania czasu pracy ponad określony w art. 15 u.r.z.o.n. (na podstawie art. 16) oraz na podobnej zasadzie zastosowania wobec takich pracowników systemu równoważnego czasu pracy będzie wyrażenie zgody przez lekarza. Dodatkowo warunkiem koniecznym w obu przypadkach jest złożenie wniosku przez osobę zainteresowaną, która w dniu składania go musi pozostawać w zatrudnieniu - a zatem nie można wystąpić o taką zgodę jeszcze przed podjęciem zatrudnienia. Powyższe zapobiega sytuacji, w której pracodawca warunkuje zatrudnienie osoby niepełnosprawnej 
od uzyskania zgody lekarza, obawiając się konieczności stosowania skróconych norm czasu pracy (Staszewska 2015, s. 381-382).

Istnieje jeszcze jedna regulacja prawna swoista dla pracowników instytucji kultury, mianowicie art. 26c ust. 3. Przepis ten wyłącza możliwość stosowania zakazu określonego w art. $139 \$ 2$ k.p., dotyczący stosowania przerywanego czasu pracy wobec pracowników, którzy podlegają równoważnym systemom czasu pracy określonym w art. 135 k.p. Właściwe byłoby w tym miejscu zadać pytanie: jakie to ma znaczenie dla sytuacji niepełnosprawnego pracownika instytucji kultury? W zasadzie odpowiedź powinna być taka sama jak w każdym innym przypadku omówionych powyżej szczegółowych regulacji dotyczących określonego rodzaju zawodów, a zatem przede wszystkim jest to zależne od zezwolenia lekarza oraz woli niepełnosprawnego pracownika.

\subsection{Czas pracy niepełnosprawnych członków korpusu służby cywilnej}

Pewne wątpliwości może budzić regulacja czasu pracy widoczna w odniesieniu do członków korpusu służby cywilnej. Należy rozpocząć od wskazania, iż czas pracy tej grupy zawodowej reguluje ustawodawca na gruncie trzech aktów prawnych. W pierwszej kolejności jest to ustawa $\mathrm{z}$ dn. 21 listopada 2008 r. o służbie cywilnej (Dz.U. 2018, poz. 1559 tekst jedn., dalej: „ustawa o służbie cywilnej”, ,u.s.c.”), ponadto Kodeks pracy, który znajduje zastosowanie na podstawie art. 9 ust. 1 u.s.c., a następnie Rozporządzenie Prezesa Rady Ministrów z dn. 25 kwietnia 2007 r. w sprawie czasu pracy pracowników urzędów administracji rządowej (Dz.U. 2007, nr 76, poz. 505), określające zasady ustalania przez dyrektora generalnego urzędu rozkładu czasu pracy w tygodniu oraz jego wymiaru w poszczególnych dniach tygodnia. Mająca podstawowe znaczenie w omawianym zakresie ustawa o służbie cywilnej reguluje czas pracy członków korpusu służby cywilnej jako nieprzekraczający 8 godzin na dobę i średnio 40 godzin tygodniowo w przyjętym okresie rozliczeniowym nie dłuższym niż 8 tygodni (art. 97 ust. 1 u.s.c.). W sytuacjach uzasadnionych rodzajem i organizacją pracy ustawodawca dopuszcza stosowanie rozkładów czasu pracy, w których możliwe jest przedłużenie czasu pracy do 12 godzin na dobę, jednakże w tych rozkładach czas pracy nie może przekraczać średnio 40 godzin na tydzień w przyjętym okresie rozliczeniowym nie dłuższym niż 12 tygodni (art. 97 ust. 2 u.s.c.)

Podkreślić należy, że zarówno w przypadku pracowników służby cywilnej, jak i w powyżej omówionym przypadku pracowników instytucji kultury szczególna regulacja wykonywania określonego rodzaju pracy (jako sui generis pragmatyka zawodowa) nie zmienia regulacji ani też nie deroguje postanowień ustawy o rehabilitacji zawodowej i społecznej oraz zatrudnianiu osób niepełnosprawnych, natomiast wprowadza kolejne rozszerzenie wyjątków uregulowanych w Kodeksie pracy (art. 137 w zw. z art. $135 \$ 2$ i 3 k.p.), dotyczących możliwości zastosowania równoważnego systemu czasu pracy, poprzez przedłużenie dobowego czasu pracy oraz okresu rozliczeniowego.

Reasumując, omówione w tym i poprzednim podrozdziale regulacje prawne są możliwe do zastosowania w przypadku przeprowadzenia następującej procedury wobec niepełnosprawnego pracownika: 
I. zaistnienie potrzeby zastosowania „wydłużonego czasu pracy” wobec niepełnosprawnego pracownika, wynikającej z ustawy lub potrzeb pracodawcy, uzasadnionej rodzajem pracy (w tym przypadku w porozumieniu z Państwową Inspekcją Pracy),

II. złożenie wniosku niepełnosprawnego pracownika o zastosowanie wobec niego „wydłużonego czasu pracy”,

III. uzyskanie przez niepełnosprawnego pracownika zgody lekarza na wykonywanie pracy w tym systemie (Lisowski, Stradomski 2018, s. 321).

Ponadto - co ważne z punktu widzenia celu niniejszej publikacji - w pierwszej wymienionej powyżej regule dotyczącej ośmiogodzinnego czasu pracy dobowej i czterdziestogodzinnego tygodniowo ustawodawca używa sformułowania „nie może przekraczać", które mogłoby prowokować pracodawcę publicznego do określania dobowej normy czasu pracy na niższym niż osiem godzin poziomie. Jednakże ani doktryna, ani praktyka nie dopuszczają takiego działania. Należy mieć na uwadze szczególny charakter zatrudnienia urzędników, gdyż jest to służba publiczna świadczona głównie w interesie publicznym i finansowana ze środków publicznych (Ciepła 2010, s. 222), a zatem obniżanie norm czasu pracy może w tym przypadku budzić kontrowersje. Natomiast nie ulega wątpliwości, że skrócone normy czasu pracy będą obowiązywać także w sferze publicznej, w przypadku gdy będzie to wynikać z przepisów szczególnych o charakterze ochronnym w stosunku do niepełnosprawnych pracowników służby cywilnej, takich jak na przykład art. 15 u.r.z.o.n.

\subsection{Czas pracy niepełnosprawnych pracowników podmiotów leczniczych}

Odmiennie niż na gruncie ustawy o rehabilitacji zawodowej i społecznej oraz zatrudnianiu osób niepełnosprawnych ustawodawca reguluje nomy czasu pracy niepełnosprawnych pracowników podmiotów leczniczych na podstawie regulacji ustawy z dn. 15 kwietnia 2011 r. o działalności leczniczej (Dz.U. 2018, poz. 2190 tekst jedn. ze zm. dalej: „ustawa o działalności leczniczej”, „dział. lecz.”). Na wstępie zasadne wydaje się choć zasygnalizowanie, iż podmiotem wykonującym działalność leczniczą jest podmiot leczniczy (w rozumieniu art. 4 dział. lecz. są to m.in. przedsiębiorcy, samodzielne publiczne zakłady opieki zdrowotnej, jednostki budżetowe instytuty badawcze, jednostki wojskowe) oraz lekarz, pielęgniarka lub fizjoterapeuta wykonujący zawód w ramach działalności leczniczej jako praktykę zawodową. Wskazana definicja podmiotu wykonującego działalność leczniczą wynika z nowego brzmienia ustawy o działalności leczniczej, które będzie obowiązywało od dn. 1 kwietnia 2019 r. (Dz.U. 2018, poz. 2219), a novum stanowi poszerzenie kręgu podmiotów o fizjoterapeutów.

Wracając do dyskutowanego zagadnienia czasu pracy, należy sięgnąć do art. 93 ust. 1 dział. lecz., który ustanawia dla pracowników zatrudnionych w podmiocie leczniczym jako zasadę dobowej normy czasu pracy 7 godzin 35 minut oraz tygodniowej - 37 godzin 55 minut w przeciętnym okresie rozliczeniowym. Jednakże w dalszej treści przedmiotowego artykułu ustawodawca przewiduje dwa wyjątki od tej zasady. Pierwszy dotyczy pracowników technicznych, obsługi i gospodarczych, których 
czas pracy w przyjętym okresie rozliczeniowym nie może przekraczać 8 godzin na dobę i przeciętnie 40 godzin na tydzień (art. 93 ust. 2 dział. lecz.). Drugi dotyczy pracowników niewidomych zatrudnionych na stanowiskach wymagających kontaktu z pacjentami, których czas pracy w przyjętym okresie rozliczeniowym nie może przekraczać 6 godzin na dobę i przeciętnie 30 godzin na tydzień (art. 93 ust. 3 dział. lecz.). Należy zauważyć, iż na gruncie ustawy o rehabilitacji zawodowej i społecznej oraz zatrudnianiu osób niepełnosprawnych brak jest definicji pojęcia „osoba niewidoma”. W tym zakresie należy sięgnąc do standardów postępowania dla lekarzy orzeczników, które za całkowicie niewidomą uznają osobę, która nic nie widzi i nie ma poczucia światła. Dla celów prawnych dotyczących kwestii społecznych rozróżniają różne stopnie utraty wzroku, takie jak: osoba bez poczucia światła - całkowicie niewidoma, osoba, której ostrość wzroku oka lepszego po korekcji szkłami nie przekracza 2,5/50 lub 3/60 $(0,05)$, jak również osoba z ograniczonym polem widzenia poniżej 20 stopni, niezależnie od zachowanej ostrości wzroku - prawie niewidoma (Definicja... 2016/2019).

$\mathrm{W}$ świetle powyższego należy podkreślić, iż w praktyce - w celu zapewnienia wsparcia na zatrudnienie niewidomych osób niepełnosprawnych - przyjmuje się, że określenie osób z dysfunkcją narządu wzroku wyrażone w art. 93 ust. 3 dział. lecz. za pomocą potocznego sformułowania „osoba niewidoma” obejmuje swoim zakresem osoby z dysfunkcją narządu wzroku w stopniu znacznym i umiarkowanym.

Należy także zauważyć, iż regulacją szczególną - w zakresie przeciętnych dobowych norm czasu pracy pracowników zatrudnionych w podmiocie leczniczym - w stosunku do wyżej wymienionego art. 93 dział. lecz. jest norma art. 94 ust. 1 tej ustawy. Przewiduje ona możliwość przedłużenia przeciętnej dobowej normy czasu pracy do maksymalnie 12 godzin dla rozkładu czasu pracy pracowników w ramach równoważnego systemu czasu pracy. Przedłużony dobowy wymiar czasu pracy jest równoważony krótszym dobowym wymiarem czasu pracy w niektórych dniach lub dniami wolnymi od pracy. Wprowadzenie systemu równoważnego czasu pracy musi być uzasadnione organizacją lub rodzajem pracy, jak również wymaga istnienia obiektywnych i stabilnych powodów. Jednakże możliwość zastosowania równoważnego czasu pracy dotyczy pracowników technicznych, gospodarczych i obsługi, a także pracowników działalności podstawowej. Natomiast nie dotyczy pracowników niewidomych zatrudnionych na stanowiskach wymagających kontaktu z pacjentami, co wprost wynika z zastrzeżenia ujętego w art. 94 ust. 1 dział. lecz.

\subsection{Indywidualny czas pracy pracownika będącego rodzicem dziecka niepełnosprawnego}

Ostatnie nowelizacje Kodeksu pracy przyniosły pewnego rodzaju novum - zresztą bardzo pożądane - dotyczące możliwości złożenia wniosku o ustalenie indywidualnego rozkładu czasu pracy pracownika, rodzica dziecka niepełnosprawnego o umiarkowanym lub znacznym stopniu niepełnosprawności. 
W indywidualnym rozkładzie czasu pracy możliwe jest w szczególności określenie innych dni oraz godzin rozpoczynania i kończenia pracy, niż w odniesieniu do ogółu pracowników, co pozwala uwzględnić specyficzne potrzeby konkretnych pracowników, ułatwiając godzenie pracy z obowiązkami osobistymi oraz rodzinnymi. Ze względu na charakter rozwiązania przyjętego w art. 142 k.p. indywidualny rozkład czasu pracy może być wprowadzony jedynie na wniosek pracownika (Pisarczyk 2017, s. 844-845).

Regulację tę wprowadzono dodanym art. $142^{1} \S .1$ pkt 3) lit. a k.p., wedle którego pracodawca jest obowiązany uwzględnić wniosek pracownika będącego rodzicem dziecka legitymującego się orzeczeniem o niepełnosprawności (określonym w przepisach o rehabilitacji zawodowej i społecznej oraz zatrudnianiu osób niepełnosprawnych) o ustalenie indywidualnego rozkładu czasu pracy kategorii pracowników wymienionych w art. $142^{1}$ k.p., znajdujących się w sytuacjach wymienionych w tym przepisie. Przepis art. $142^{1}$ k.p. jest odstępstwem od zasady wyrażonej w art. 142 k.p., zgodnie z którym pracodawca ma możliwość ustalenia indywidualnego rozkładu czasu pracy tych pracowników, którzy zwrócą się do niego z pisemnym wnioskiem w tej sprawie. Powyższe uprawnienie nie ma charakteru bezwzględnego, pracodawca może bowiem odmówić uwzględnienia wniosku złożonego przez pracownika wymienionego $\mathrm{w}$ art. $142^{1} \mathrm{k}$.p., jeżeli jego uwzględnienie nie jest możliwe ze względu na organizacje pracy lub rodzaj pracy wykonywanej przez pracownika (Świątkowski 2018, s. 842). W tym miejscu zauważyć należy, że tego rodzaju wniosek pracownika w zakładzie pracy chronionej należałoby rozpatrzyć ze szczególną atencją.

\section{Zakończenie}

Powyższe regulacje ilustrują różnorodność w zakresie regulacji czasu pracy osób niepełnosprawnych, który de facto zależny jest od rodzaju wykonywanego zawodu. Szeroko omówione w niniejszym opracowaniu regulacje prawne dają jednak do myślenia, gdyż można spostrzec wiele ich niedoskonałości. Podkreśla się, że kontakt z czynnymi zawodowo osobami niepełnosprawnymi i praktyka ich zatrudniania wskazują na niedoskonałość regulacji prawnych w tym zakresie, zwłaszcza pod kątem potrzeb osób niepełnosprawnych (Kuźniar 2015). Warto zaznaczyć, że obecna wysokość świadczeń rentowych jest na tak niskim poziomie, iż osoby niepełnosprawne - zwłaszcza te, które wymagają stałej opieki lekarskiej i leczenia - są wręcz zmuszone podejmować zatrudnienie (ze względu na przykład na koszt leków).

Nowelizacja przepisów Kodeksu pracy uelastyczniła w znacznej mierze przepisy z zakresu czasu pracy. Nie przewidziano w niej jednak żadnych wyjątków wobec pracowników, których warunki zatrudnienia ze względu na czynniki techniczne, organizacyjne czy ludzkie powinny podlegać szczególnej ochronie. Jedną z takich grup pracowników są niewątpliwie niepełnosprawni, których warunki zatrudnienia ze względu na ten ostatni czynnik powinny być w pewnym zakresie uprzywilejowane (Kuźniar 2015, Legalis). 
W związku z tym wypada postulować do ustawodawcy o zmianę przepisów ustawy o rehabilitacji zawodowej i społecznej oraz zatrudnianiu osób niepełnosprawnych, która zachęci pracodawców do zatrudniania pracowników niepełnosprawnych. Zmiana ta miałaby nie tylko dotyczyć kwestii refundacji kosztów zatrudnienia, ale przede wszystkim stworzyć narzędzia dla stosowania specyficznych systemów zatrudniania takich pracowników, jak choćby przerywany czas pracy czy możliwość wykonywania zadań służbowych poza miejscem pracy (w domu) - jak wspomniano we wstępie, byłaby to pełna realizacja definicji czasu pracy wynikającej z prawa unijnego.

Konstatując, należy spoglądać na tę grupę pracowniczą, którą stanowią przecież osoby niepełnosprawne, jako na grupę, która nie chce być w jakikolwiek sposób „dotowana” przez państwo. To ludzie, którzy chcą aktywnie uczestniczyć w życiu społecznym i zawodowym, kolokwializując: chcą czuć się potrzebni społeczeństwu i realizować się zawodowo. Nie wolno patrzeć na pracowników niepełnosprawnych jak na osoby nieproduktywne (choćby ze względu na obowiązywanie wobec nich niższego wymiaru czasu pracy), a należy postrzegać ich jako grupę społeczną o ogromnym potencjale zawodowym i społecznym.

Warto na zakończenie podzielić się smutnym spostrzeżeniem, że osoby niepełnosprawne postrzegane są w naszym społeczeństwie jako pracownicy „gorszej kategorii”, tymczasem wiele przykładów osób niepełnosprawnych, które osiągnęły sukces zawodowy, przeczy takiej stereotypowej opinii. Może zatem to my, „pełnosprawni”, nie potrafimy wykorzystać potencjału osób niepełnosprawnych, co chyba nie najlepiej o nas świadczy.

\section{Bibliografia}

Baran K.W. (2018) [w:] K.W. Baran (red.), Kodeks pracy. Komentarz, Warszawa.

Barański A., Szymańska M.H., Rozwadowska-Skrzeczyńska J. (2018) Karta nauczyciela. Komentarz, Warszawa.

Bury B. (2007) Praca w godzinach nadliczbowych jako obowiązek pracownika, Warszawa.

Ciepła H. (2010) Stosunki pracy w stużbie cywilnej, Warszawa.

Definicja osoby niewidomej (2016/2019) http://fazon.pl/index.php?option=com_content\&view =article\&id=242:definicja-osoby-niewidomej\&catid=14\&Itemid=142 (dostęp: 4.02.2019).

Dörre-Kolasa D. (2018) [w:] A. Sobczak (red.), Kodeks pracy. Komentarz, Warszawa.

Gajewski S., Jakubowski A. (2016) Ustawa o organizowaniu i prowadzeniu działalności kulturalnej-komentarz, Warszawa.

Gersdorf M. (2004) O pojęciu pracy w godzinach nadliczbowych polemicznie, „Praca i Zabezpieczenie Społeczne", nr 3.

Klimkiewicz L. (2011) Czas pracy osób niepełnosprawnych, cz. 2, „Służba Pracownicza”, nr 1.

Kurzynowski A. (1996) Regionalna polityka społeczna - uwagi ogólne [w:] A. Kurzynowski (red.), Bezrobocie w piątym roku transformacji gospodarczej w Regionie Pótnocno-Wschodnim, Warszawa. 
Kuźniar A. (2015) Elastyczny czas pracy pracowników niepełnosprawnych [w:] M. Bosak, (red.), Prawo a niepetnosprawność. Wybrane aspekty, Warszawa.

Lisowski K., Stradomski K. (2018) Karta Nauczyciela. Komentarz, Warszawa.

Paluszkiewicz M. (2018) [w:] K.W. Baran (red.), System prawa pracy, t. 8: Prawo rynku pracy, Warszawa.

Pisarczyk Ł. (2017) [w:] L. Florek (red.), Kodeks pracy. Komentarz, Warszawa.

Rączka K. (2004) Nowe pojęcie pracy w godzinach nadliczbowych, „Praca i Zabezpieczenie Społeczne" 2004, nr 3.

Staszewska E. (2015) [w:] M. Włodarczyk (red.), Ustawa o rehabilitacji zawodowej i społecznej oraz zatrudnianiu osób niepełnosprawnych. Komentarz, Warszawa.

Stefański K. (2018a) [w:] K.W. Baran (red.), Kodeks pracy. Komentarz, Warszawa.

Stefański K. (2018b) Prawo pracy dla sędziów i petnomocników, Warszawa.

Świątkowski A.M. (2018) Kodeks pracy. Komentarz, Warszawa.

Zieliński T., Goździewicz G. (2017) [w:] L. Florek (red.), Kodeks pracy. Komentarz, Warszawa.

\section{Orzecznictwo}

Wyrok SN z 23 czerwca 2005 r., II PK 265/04, OSNP 2006, nr 5-6, poz. 76.

Uchwała SN z 8 kwietnia 2009 r., II PZP 2/09, OSNP 2009, nr 19-20, poz. 249.

Wyrok TK z 13 czerwca 2013 r., K 17/11, Dz.U. 2013, poz. 791. 